\title{
Evaluating Genetic Variability of Sorghum Mutant Lines Tolerant to Acid Soil
}

\author{
W. Puspitasari ${ }^{* 1}$, S. Human ${ }^{1}$, D. Wirnas ${ }^{2}$ and Trikoesoemaningtyas \\ ${ }^{1}$ Center for the Application of Isotope and Radiation Technology, National Nuclear Energy Agency \\ Jl. Lebak Bulus Raya, No. 49, Jakarta 12440, Indonesia \\ ${ }^{2}$ Department of Agronomy and Horticulture, Bogor Agricultural University, Indonesia
}

\section{ARTICLE INFO}

Article history:

Received 05 December 2011

Received in Revised form 21 June 2012

Accepted 02 July 2012

Keywords:

Sorghum mutant lines

Sorghum bicolor (L.) moench

Acid soil

Genetic variability

\begin{abstract}
A B S T R A C T
High rainfall in some parts in Indonesia causes soil become acidic. The main constraint of acid soil is phosphor $(\mathrm{P})$ deficiency and aluminum $(\mathrm{Al})$ toxicity which decrease plant productivity. To overcome this problem, it is important to develop a crop variety tolerant to such conditions. Sorghum is probably one of the potential crops to meet that objective. Sorghum has been reported to have wide adaptability to various agro-ecology and can be used as food and animal feed. Unfortunately, sorghum is not Indonesian origin so its genetic variability is still low. From previous breeding works with induced mutation, some promising mutant lines have been developed. These mutant lines were included in the experiment carried out in Tenjo with soil condition was classified as acid soil with $\mathrm{pH} 4.8$ and exchangeable-Al content $2.43 \mathrm{me} / 100 \mathrm{~g}$. The objectives of this experiment were to study the magnitude of genetic variability of agronomy and grain quality characters in sorghum in order to facilitate the breeding improvement of the species. Plant materials used in this study were ten genotypes, including 6 mutant lines and 4 control varieties. The randomized block design with three replications was used in the experiment. The genetic variabilities of agronomic and grain quality characters existed among genotypes, such as plant height, number of leaves, stalk diameter, biomass weight, panicle length, grain yield per plant, 100 seed weight and tannin content in the grain. The broad sense heritabilities of agronomic characters were estimated ranging from medium to high. Grain yield showed significantly positive correlation with agronomic characters observed, but it was negatively correlated with protein content.
\end{abstract}

(C) 2012 Atom Indonesia. All rights reserved

\section{INTRODUCTION}

The potential of land resources in Indonesia, especially in agriculture, is extensive, including dry and wet land. Dry land area in Indonesia reached 148 million ha, and $69.5 \%$ of dry land is acid soil with $\mathrm{pH}$ conditions less than 5.5 [1]. Climate variations and relatively high rainfall in most parts of Indonesia resulted in intensive mineral leaching in the soil, so the basic content reduced and the soil becomes acidic. The main issue on dry acid soil is phosphor $(\mathrm{P})$ deficiency and aluminum $(\mathrm{Al})$ toxicity which decrease plant productivity, thus it is important to develop crop varieties such as sorghum, which can adapt to dry and acid soil and exhibit high yield.

Sorghum (Sorghum bicolor (L.) Moench) is one of major food crops in the world. Beside the content of carbohydrates, it contains protein, iron and vitamin B3 which are higher than rice and

\footnotetext{
* Corresponding author.

E-mail address: winda_p@batan.go.id
}

maize [2]. Sorghum has low gluten content and glycemic index, so it is suitable for specific nutritional diet [3]. In Africa, sorghum grain consumed in the form of unleavened breads, boiled porridge or gruel, malted beverages, beer, popped grain and chips. Sorghum has wide adaptability to various agro-ecology, especially its tolerance to drought [4].

Genetic variability of sorghum in Indonesia is still low because sorghum is not originated from Indonesia and not commonly cultivated. Enhancement of genetic variability of sorghum can be conducted through plant mutation breeding techniques. Gamma ray irradiation on plant mutation breeding is often used to improve plant characters in order to obtain high yielding varieties in plant breeding program.

Centre for Application of Isotope and Radiation Technology, BATAN, has developed some mutant lines tolerant to acid soil through mutation breeding [5]. Genetic material used in this study was selected materials from the previous research. This study was focusing on observation of 
agronomic and grain quality characters in order to both study the magnitude of genetic variability in sorghum and facilitate the breeding improvement of the species.

The present study provides information of the genetic parameters such as variance and heritability of agronomic and quality characters of sorghum genotypes (mutant lines and varieties) tolerant to acid soil. Correlation and path analysis was performed to study the effect of some characters on grain yield.

\section{EXPERIMENTAL METHODS}

The experiment was conducted in Unit of Technical Implementation (UPT) of Dry Land Technologies of West Bogor in Tenjo on FebruaryMay 2011. The soil condition was classified as acid soil with $\mathrm{pH} 4.8$ and exchangeable-Al content $2.43 \mathrm{me} / 100 \mathrm{~g}$. Randomized block design using three replications was used in the experiment.

Ten genotypes were used as genetic materials in the experiment, consisted of six sorghum mutant lines derived from gamma irradiation of Durra and Zhengzu varieties (GH-ZB41-07, ZH30-29-07, BR-ZH30-07-07, Patir-cty 33, B-76, B-92) and four control varieties (Kawali, Numbu, Mandau and Higari).

The measurement of agronomic characters comprised of plant height $(\mathrm{cm})$, number of leaves, stalk diameter $(\mathrm{cm})$, biomass weight $(\mathrm{g})$, panicle length $(\mathrm{cm})$, grain yield per plant $(\mathrm{g})$ and 100 seed weight (g). The observation of grain sorghum quality consisted of the analysis of amylose, protein and tannin content. Amylose content was determined using iodo-colorimetry method [7], protein content was analyzed by Kjeldahl method [8] and tannin content was analyzed by the vanillin in acidic methanol method [9].

Analysis of variance was carried out following the standard procedures. From the anova table genetic variance as well as phenotypic variance for characters was counted. Broad sense heritability was estimated by comparison of genetic variance with phenotypic variance, heritability is high if more than $50 \%$, medium range from $20-50 \%$ and low under $20 \%$. Genetic variability was calculated based on standard deviation of genetic variance by Anderson and Brancoft method [10], genetic variable is wide if $\sigma_{g}^{2}>2 \sigma_{\sigma_{g}^{2}}$ and narrow if $\sigma_{g}^{2}<2 \sigma_{\sigma_{g}^{2}}$. Pearson coefficient correlation and path analysis were computed based on Roy [11].

\section{RESULTS AND DISCUSSION}

Analysis of variance indicated significant differences $(\mathrm{P}<0.05)$ for all agronomic characters among genotypes (data not presented). Agronomic performances of genotypes are presented in Table 1. The highest genotype was Numbu reached $203.38 \mathrm{~cm}$, while the lowest was Mandau $(119.10 \mathrm{~cm})$. Plant height of sorghum mutant lines was ranging from 138.11-189.47 cm. Plant height is an important character because it can describe the proportion of photosynthate allocation between the stem and grain. For grain sorghum purpose, very high plants are not desirable because it will reduce the photosynthate allocation to grain production [12]. In addition, medium height sorghum is generally associated with lodging resistance. Mutant lines of GH-ZB-41-07, Br-ZH-30-07-07 and B-76 could potentially be developed into semi dwarf sorghum.

Table 1. Data of agronomic characters of sorghum genotypes grown in acid soil

\begin{tabular}{lccccc}
\hline \multicolumn{1}{c}{ Genotypes } & $\begin{array}{c}\text { Plant } \\
\text { Height } \\
(\mathrm{cm})\end{array}$ & $\begin{array}{c}\text { Biomass } \\
\text { Weight } \\
(\mathrm{g})\end{array}$ & $\begin{array}{c}\text { Panicle } \\
\text { Length } \\
(\mathrm{cm})\end{array}$ & $\begin{array}{c}\text { 100 Seed } \\
\text { Weight } \\
(\mathrm{g})\end{array}$ & $\begin{array}{c}\text { Grain } \\
\text { Yield } \\
(\mathrm{g})\end{array}$ \\
\hline GH-ZB-41-07 & $152.44 \mathrm{c}$ & $240.10 \mathrm{de}$ & $23.28 \mathrm{ab}$ & $2.38 \mathrm{~cd}$ & $48.28 \mathrm{c}$ \\
Patir-cty 33 & $189.47 \mathrm{ab}$ & $359.57 \mathrm{bc}$ & $24.03 \mathrm{ab}$ & $3.04 \mathrm{bc}$ & $54.23 \mathrm{bc}$ \\
Br-ZH-30-07-07 & $138.11 \mathrm{~cd}$ & $372.17 \mathrm{bc}$ & $27.10 \mathrm{a}$ & $2.52 \mathrm{bc}$ & $39.29 \mathrm{~cd}$ \\
Zh-30-29-07 & $185.90 \mathrm{ab}$ & $346.08 \mathrm{bc}$ & $25.75 \mathrm{a}$ & $2.83 \mathrm{bc}$ & $47.05 \mathrm{~cd}$ \\
B-76 & $154.47 \mathrm{c}$ & $263.65 \mathrm{~cd}$ & $20.85 \mathrm{~b}$ & $2.07 \mathrm{~d}$ & $45.71 \mathrm{~cd}$ \\
B-92 & $175.19 \mathrm{~b}$ & $332.05 \mathrm{~cd}$ & $21.84 \mathrm{~b}$ & $2.63 \mathrm{bc}$ & $56.82 \mathrm{bc}$ \\
Higari & $121.83 \mathrm{de}$ & $155.11 \mathrm{e}$ & $21.20 \mathrm{~b}$ & $2.71 \mathrm{bc}$ & $27.42 \mathrm{~d}$ \\
Kawali & $176.23 \mathrm{~b}$ & $717.57 \mathrm{a}$ & $25.96 \mathrm{a}$ & $3.14 \mathrm{ab}$ & $100.37 \mathrm{a}$ \\
Numbu & $203.38 \mathrm{a}$ & $465.26 \mathrm{~b}$ & $20.77 \mathrm{~b}$ & $3.77 \mathrm{a}$ & $71.85 \mathrm{~b}$ \\
Mandau & $119.10 \mathrm{e}$ & $268.80 \mathrm{~cd}$ & $26.08 \mathrm{a}$ & $2.11 \mathrm{~d}$ & $44.70 \mathrm{~cd}$ \\
\hline
\end{tabular}

Values followed by a common letter within a column are not

significantly different as indicated by Least significant difference test at $\mathrm{p}=0.05$

Biomass weight of mutant lines ranged between 240.10-372.17 g, which was still lower than biomass weight of Kawali and Numbu. The ability of plants in maintaining weight biomass plants showed tolerance capacity against acid soil [13]. For feed purpose, biomass weight is an important character. The highest biomass weight will supply forage for feed.

Panicle length, 100 seed weight and grain yield are grain yield components, which means that the characters contribute to total grain weight. Panicle length of mutant lines ranges from 20.85-27.10 cm, while that of the control varieties ranges from 20.77-25.96 cm. Panicle length is one of important component because it is a place for panicle branches containing grains. 100 seed weight of mutant lines range from 2.07-3.04 $\mathrm{g}$ and the controls ranges from 2.11-3.14 g. 100 seed weight is associated with seed size. Grain yield per plant was ranging from 39.29-56.82 $\mathrm{g}$ for mutant lines and ranging from 
27.42-100.37 $\mathrm{g}$ for control varieties. Even though grain yield of mutant lines still lower than Kawali and Numbu, the mutant lines were promising for the cultivation because of their tolerance to acid soil.

Table 2. Data of grain quality characters of sorghum genotypes grown in acid soil

\begin{tabular}{llrl}
\hline \multicolumn{1}{c}{ Genotypes } & $\begin{array}{c}\text { Amylose } \\
(\%)\end{array}$ & $\begin{array}{c}\text { Protein } \\
(\%)\end{array}$ & $\begin{array}{c}\text { Tannin } \\
\left(\begin{array}{c}\text { m cathecin } \\
/ 100 \mathrm{~g})\end{array}\right.\end{array}$ \\
\hline GH-ZB-41-07 & $23.89 \mathrm{ab}$ & $9.56 \mathrm{a}$ & $0.65 \mathrm{~b}$ \\
Patir-cty 33 & $24.39 \mathrm{ab}$ & $9.43 \mathrm{a}$ & $0.82 \mathrm{~b}$ \\
Br-Zh-30-07-07 & $24.42 \mathrm{ab}$ & $10.93 \mathrm{a}$ & $0.57 \mathrm{~b}$ \\
Zh-30-29-07 & $24.85 \mathrm{a}$ & $10.30 \mathrm{a}$ & $0.38 \mathrm{~b}$ \\
B-76 & $23.36 \mathrm{ab}$ & $10.12 \mathrm{a}$ & $0.48 \mathrm{~b}$ \\
B-92 & $22.37 \mathrm{~b}$ & $8.87 \mathrm{a}$ & $0.58 \mathrm{~b}$ \\
Higari & $24.65 \mathrm{ab}$ & $10.16 \mathrm{a}$ & $0.51 \mathrm{~b}$ \\
Kawali & $24.12 \mathrm{ab}$ & $9.40 \mathrm{a}$ & $0.46 \mathrm{~b}$ \\
Numbu & $24.57 \mathrm{ab}$ & $10.03 \mathrm{a}$ & $0.60 \mathrm{~b}$ \\
Mandau & $24.82 \mathrm{a}$ & $9.88 \mathrm{a}$ & $3.66 \mathrm{a}$ \\
\hline
\end{tabular}

Values followed by a common letter within a column are not significantly different as indicated by Least significant difference test at $\mathrm{p}=0.05$

Sorghum grain contains starch, which consist of amylose and amylopectin. The ratio of amylose and amylopectin influences physicochemical, thermal and rheological properties of starch. Amylose content of sorghum genotypes ranged between $22.37-24.82 \%$. Sorghum is classified into three group based on the amylose content, namely waxy $(<1 \%)$, heterowaxy $(10-20 \%)$ and normal (>20\%). The endosperm of waxy sorghum contains three recessive waxy genes (wxwxwx), heterowaxy sorghum contains at least one recessive gene (WxWxwx or Wxwxwx), and normal sorghum contains no recessive gene (WxWxWx) [14]. With regard to the description, all sorghum genotypes in the experiment were classified into normal sorghum.

The experiment results showed that protein content range from $8.87-10.93 \%$ and no significant difference among genotypes. As cereal plant, the protein content of sorghum is low, generally ranging from $8-11 \%$ [15]. However, the protein content of sorghum is higher than rice and maize. The protein content differ depend on the growing condition and genetics. The highest protein content was shown by mutant line Br-ZH-30-07-07.

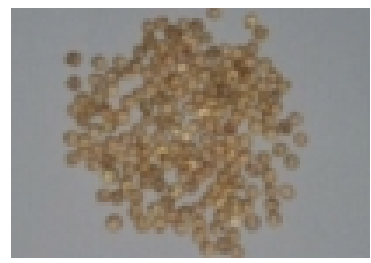

GH-ZB-41-07

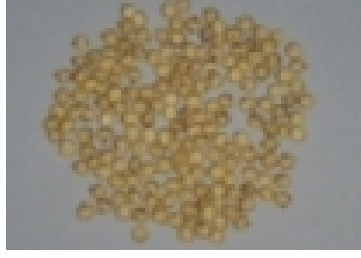

Patir-cty 33
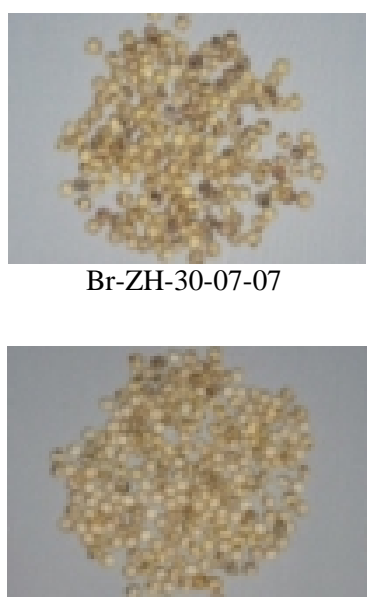

B-76

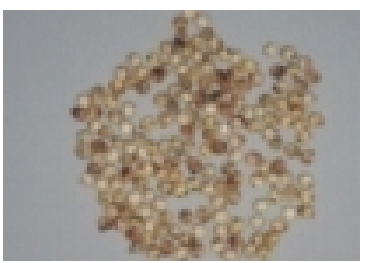

Higari

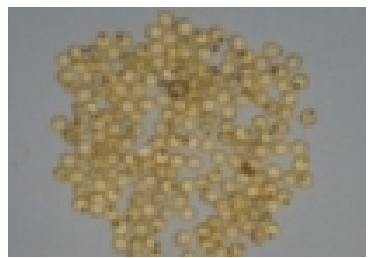

Numbu
Br-ZH-30-07-07

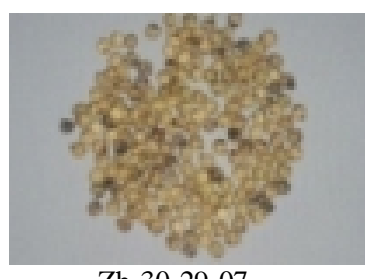

Zh-30-29-07

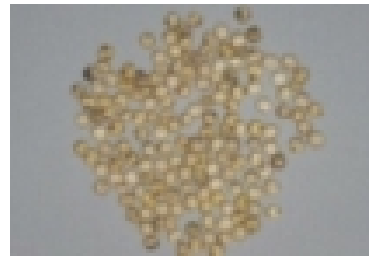

B-92

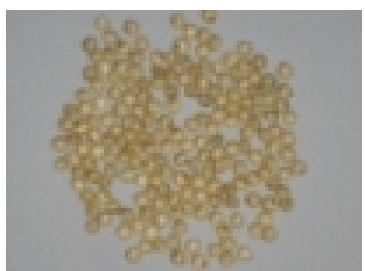

Kawali

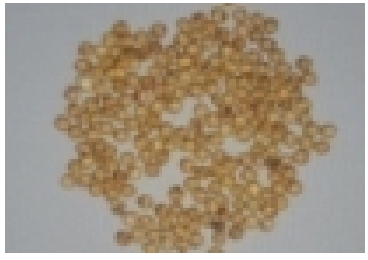

Mandau
Fig. 1. Variability of grain sorghum genotypes grown in acid soil.

The tannin content of genotypes ranges from 0.38-3.66 mg (cathecin/100 mg), the highest was Mandau with $3.66 \mathrm{mg}$. Sorghum is divided into three groups based on the level of phenol present (primarily tannin); Group I contains low level of phenol and no tannin; Group II contains tannin which can be extracted by acidic methanol but not by methanol alone, and Group III contains tannin can be extracted by both methanol and acidic methanol. According to various studies summarized by Dykes and Rooney [16], analysis by the same method reveals that tannin content of sorghum Group I ranges from $0.00-0.18 \mathrm{mg}$ (all data below the detection limit), tannin content of Group II ranged $0.64-1.55 \mathrm{mg}$, and the tannin content of Group III ranged 1.10-5.63 mg. The analysis showed that all genotypes had tannin, that is nine genotypes were classified into sorghum type II, while Mandau was grouped into type III.

Tannin content is one of important qualities in sorghum grain, especially for food, because of its 
effects to human health and sorghum palatability. The presence of tannin can make food taste bitter. Tannin is known as anti-nutritional compounds that can reduce nutrient in food. But, tannin content is estimated also associated with the presence of several polyphenolic compounds that are useful for medicine [17]. Therefore, the presence of tannins is still required but in low levels. All sorghum mutant line had low tannin so they are potentially to be developed as food.

Sometimes tannin content is estimated by the color of sorghum grain (pericarp), for example white or yellow has no tannin and brown or red sorghum has high content of tannin. The observation of sorghum color of genotypes showed that GH-ZB41-07 (brown) had low tannin level, while the other eight genotypes (white and yellow) also had low tannin level (Fig. 1). Mandau (brown) was the highest tannin content compared to other genotypes. These results indicated that grain color had no association with tannin content.

The estimation of heritability is used to get information of the proportion of genetic variability compared to environment variability. Heritability is used as prediction for breeder about the possibility of character inheritance. Broad sense heritabilities of all agronomic characters of the sorghum genotypes in acid soil were high and medium, which showed that all genotypes gave genetic contribution to the plant performance (Table 3). In addition, high heritability value indicating the selection of the promising mutant can be effective. Study of genetic variability was done according to the standard deviation of genetic variance of each character. Genetic variability was wide to characters such as plant height, number of leaves, biomass weight, grain yield and tannin content, while it was narrow for panicle length and 100 seed weight.
Table 3. Heritability and genetic variability values of characters of sorghum genotypes

\begin{tabular}{lccrl}
\hline \multicolumn{1}{c}{ Characters } & \multicolumn{2}{c}{$\begin{array}{c}\text { Broad Sense } \\
\text { Heritability }(\%)\end{array}$} & \multicolumn{2}{c}{$\begin{array}{c}\text { Genetic } \\
\text { Variability }\left(\mathcal{J}_{\sigma \mathrm{g}}\right)\end{array}$} \\
\hline $\begin{array}{l}\text { Plant height } \\
\text { Number of } \\
\text { leaves }\end{array}$ & 87.37 & High & 359.59 & Wide \\
Stalk diameter & 52.06 & High & 0.02 & Narrow \\
Biomass & 81.81 & High & 101.22 & Wide \\
Panicle length & 45.52 & Medium & 2.58 & Narrow \\
Grain Yield & 70.68 & High & 172.89 & Wide \\
100 seed weight & 54.93 & High & 0.11 & Narrow \\
Tannin & 78.87 & High & 0.399 & Wide \\
\hline
\end{tabular}

The study of correlation between characters resulted that all agronomic characters had significant and positive coefficient correlation (Table 4), indicated that those characters give positive contribution to grain yield. The results meant that the increase of characters value will raise the grain yield. The highest coefficient correlation to grain yield was biomass weight (0.94)

Protein content had negative correlation to grain yield, indicated that the increase of protein content will reduce grain yield. Calderon et al. [18] was also observed significantly negative correlation between protein and grain yield. The negative association between grain yield and protein content is probably caused by dilution of protein by nonnitrogen compounds (carbohydrates) in the grain. The increase of protein content requires more photosynthate, thus decreasing available photosynthate for carbohydrate synthesis and leading to relative decreases in grain yield [19].

Table 4. Correlation coefficient between characters of sorghum genotypes in acid soil

\begin{tabular}{cccccccccc}
\hline Characters & GY & PH & NL & SD & BW & PL & SW & AM & PR \\
\hline PH & $0.63^{* *}$ & & & & & & & & \\
NL & $0.81^{* *}$ & $0.51^{* *}$ & & & & & & \\
SD & $0.84^{* *}$ & $0.51^{* *}$ & $0.78^{* *}$ & & & & & & \\
BW & $0.94^{* *}$ & $0.60^{* *}$ & $0.84^{* *}$ & $0.86^{* *}$ & & & & & \\
PL & $0.37^{*}$ & $0.09^{\mathrm{ns}}$ & $0.60^{* *}$ & $0.59^{* *}$ & $0.50^{* *}$ & & & & \\
SW & $0.57^{* *}$ & $0.65^{* *}$ & $0.37^{*}$ & $0.46^{* *}$ & $0.57^{* *}$ & $0.15^{\mathrm{ns}}$ & & & \\
AM & $0.16^{\mathrm{ns}}$ & $0.10^{\mathrm{ns}}$ & $0.32^{\mathrm{ns}}$ & $0.25^{\mathrm{ns}}$ & $0.20^{\mathrm{ns}}$ & $0.16^{\mathrm{ns}}$ & $0.28^{\mathrm{ns}}$ & & \\
PR & $-0.41^{*}$ & $-0.32^{\mathrm{ns}}$ & $-0.34^{\mathrm{ns}}$ & $-0.26^{\mathrm{ns}}$ & $-0.22^{\mathrm{ns}}$ & $-0.04^{\mathrm{ns}}$ & $-0.30^{\mathrm{ns}}$ & $-0.20^{\mathrm{ns}}$ & \\
TN & $0.03^{\mathrm{ns}}$ & $-0.30^{\mathrm{ns}}$ & $0.16^{\mathrm{ns}}$ & $0.14^{\mathrm{ns}}$ & $-0.00^{\mathrm{ns}}$ & $0.24^{\mathrm{ns}}$ & $-0.28^{\mathrm{ns}}$ & $0.16^{\mathrm{ns}}$ & $-0.06^{\mathrm{ns}}$ \\
\hline
\end{tabular}

*** Significant at the 0.05 and 0.01 level of probability, ns Not significant

$\mathrm{GY}=$ grain yield, $\mathrm{PH}=$ plant height, $\mathrm{NL}=$ number of leaves, $\mathrm{SD}=$ stalk diameter, $\mathrm{BW}=$ biomass weight, PLpanicle length,

$\mathrm{SW}=100$ seed weight, $\mathrm{AM}=$ amylose content, $\mathrm{PR}=$ protein content, $\mathrm{TN}=$ tannin content 
Path analysis is a development method of correlation to differentiate direct and indirect effect of one character to the other character. Path analysis resulted in that direct effect of biomass weight on grain yield was highest and positive, and indicated that biomass weight gave big contribution to the grain production. The result was in line with the finding of Sungkono [6]. Biomass weight was used as indicator for sorghum adaptation in acid soil,
Technologies of West Bogor for assistance in conducting the experiment.

\section{REFERENCES}

1. A. Mulyani, A. Rachman and A. Dairah, Acid Soil Distribution, Potency and Availability for Agriculture, in: Natural Phosphate, Institute of Soil Research, Bogor (2009) 23. (in Indonesian).

Table 5. Direct and indirect effects of characters on grain yield in sorghum genotypes

\begin{tabular}{|c|c|c|c|c|c|c|c|c|c|c|}
\hline \multirow{2}{*}{ Characters } & \multirow{2}{*}{$\begin{array}{l}\text { Direct } \\
\text { Effect }\end{array}$} & \multicolumn{9}{|c|}{ Indirect effect via } \\
\hline & & $\mathrm{PH}$ & NL & SD & BW & PL & SW & AM & PR & $\mathrm{TN}$ \\
\hline Plant height $(\mathrm{PH})$ & 0.06 & - & -0.01 & 0.02 & 0.73 & -0.01 & 0.02 & 0.01 & 0.01 & -0.02 \\
\hline Number of leaves (NL) & -0.02 & 0.03 & - & 0.03 & 1.02 & -0.04 & 0.01 & 0.02 & 0.01 & 0.01 \\
\hline Stalk diameter (SD) & 0.04 & 0.03 & -0.01 & - & 1.05 & -0.03 & 0.02 & 0.02 & 0.01 & 0.01 \\
\hline Biomass weight (BW) & 1.22 & 0.03 & -0.01 & 0.03 & - & -0.03 & 0.02 & 0.01 & 0.01 & 0.00 \\
\hline Panicle length (PL) & -0.06 & 0.01 & -0.01 & 0.02 & 0.60 & - & 0.00 & 0.01 & 0.00 & 0.01 \\
\hline 100 seed weight $(\mathrm{SW})$ & 0.04 & 0.04 & -0.01 & 0.02 & 0.70 & -0.01 & - & 0.02 & 0.01 & -0.01 \\
\hline Amylose (AM) & 0.06 & 0.01 & -0.00 & 0.01 & 0.24 & -0.01 & 0.01 & - & 0.01 & 0.01 \\
\hline Protein (PR) & -0.04 & -0.02 & 0.01 & -0.01 & -0.26 & 0.00 & -0.01 & -0.01 & - & -0.00 \\
\hline Tannin (TN) & 0.05 & -0.02 & -0.00 & 0.01 & 0.00 & -0.01 & -0.01 & 0.01 & 0.00 & - \\
\hline
\end{tabular}

which the resistance plant will exhibit high accumulation of biomass [13]. Indirect effect of stalk diameter and number of leaves via biomass weight on grain yield were high, which indicated that biomass was important source in grain production.

The study of heritability, correlation and path analysis are used to get more information about the association between characters, especially character which is associated to grain yield. The results showed that biomass weight gave the highest effect to grain production in acid soil. Thus, biomass weight was the most suitable character for the selection of sorghum in acid soil.

\section{CONCLUSIONS}

There was significant large genetic variability of agronomic and quality characters among sorghum genotypes tolerant to acid soil. The estimation of broad sense heritabilities of agronomic characters observed was ranging from medium to high. Grain yield showed significantly positive correlation with agronomic characters observed, but it was negatively correlated with protein content. Path analysis for grain yield indicated the highest direct effect on biomass weight and it might be useful for further selection in acid soil conditions.

\section{ACKNOWLEDGEMENTS}

The authors would like to thank to Unit of Technical Implementation of Dry Land
2. B.A. Susila, Nutritional Quality and Functional Properties of Sorghum, Proceedings of the National Seminar on Postharvest Technology Innovation for AgricultureBased Industry Development (2005) 530. (in Indonesian).

3. A.D.P. Siller, In Vitro Starch Digestibility and Estimated Glycemic Index of Sorghum Products, M.Sc. Thesis, Texas A \& M University (2006).

4. T. Tesso, L.E. Claflin and M.R. Tuinstra, Crop Sci. 45 (2005) 645.

5. S. Human, Trikoesoemaningtyas, Sihono and Sungkono, Atom Indonesia 36 (2010) 11.

6. Sungkono, Sorghum Mutant Line Selection for Grain and Bioethanol Productivity Using Participatory Plant Breeding, Ph.D. Dissertation, Bogor Agricultural University (2010). (in Indonesian).

7. G. Aliawati, Agricultural Technique Bulletin 8 (2003) 82. (in Indonesian).

8. AOAC, Official Methods of Analysis of AOAC International, $18^{\text {th }}$ ed, AOAC International, Maryland (2007).

9. M.L. Price, G.V. Scoyoc and L.G. Butler, J. Agric. Food Chem. 26 (1978) 1214.

10. R. Wahdah, A. Baihaki, R. Setiamihardja and G. Suryatmana, Zuriat 7 (1996) 92. (in Indonesian). 
11. D. Roy, Plant Breeding Analysis and Exploitation of Variation, Narosa Publishing House, India (2000) 135.

12. D. Indradewa, D. Kastono and Y. Soraya, Agricultural Science 12 (2005) 117. (in Indonesian).

13. K. Agustina, Physiology Adaptation of Sorghum (Sorghum bicolor (L.) Moench) for Aluminum Toxicity and Phosphor Deficiency in Acid Soil, PhD. Dissertation, Bogor Agricultural University (2011). (in Indonesian).

14. Y. Sang, S. Bean, P.A. Seib, J. Pedersen and Y.C. Shi. J. Agric. Food Chem. 56 (2008) 6680.

15. Suarni, Journal of Agricultural Research and
Development 23 145. (in Indonesian).

16. L. Dykes and L.W. Rooney, J. Cereal Sci. 44 (2006) 236.

17. M.H. Dicko, H. Gruppen, A.S. Traore, A.G.J. Voragen and W.J.H. Van Berkel, Biotechnology and Molecular Biology Review 1 (2006) 21.

18. V.R. Calderon, L. Sandoval, L.W. Rooney and S. Mason, Grain Quality Analysis of Sorghum Samples from El Salvador, World Grain Summit: Food and Beverages, San Fransisco, USA (2006) 304.

19. Y. Rharrabti, S. Elhani, V.M. Nunez and L.V.G. Del Moral, J. Agric. Food Chem. 49 (2001) 3802. 